\title{
JULES FEIFFER'S TANTRUM AT THE END OF NARCISSISM'S DECADE
}

PAUL WILLIAMS

[S]atire concerns itself with logically extending a premise to its totally insane conclusion, thus forcing onto an audience certain unwelcome awarenesses. (92)

- Jules Feiffer, interview by Larry DuBois, 1971

Tantrum (1979) by Jules Feiffer narrates the odyssey of Leo Quog in a sequence of black and white images spread over 183 pages. Leo, a forty-two-year-old office worker with a wife and two children, screams himself back to infancy in order to escape the burdens of adult life. Feiffer is best known for the cartoons he drew for the Village Voice between 1956 and 1997. While 1950s newspaper strips had a substantial adult readership, the most popular were devised to appeal to all the family; Feiffer's comics were more obviously targeted at adults and pinpointed the modish neuroses and political hypocrisy of middle-class urbanites. Feiffer also enjoyed critical and popular success as a playwright, screenwriter, and novelist. Tantrum develops two themes apparent across Feiffer's oeuvre: male regression back to infanthood and the child traversing the adult world unaided. The latter figure can be found in Passionella and Other Stories (1959) in the form of Munro, a small boy mistakenly drafted into the army. Feiffer typically treats the regressed or immature man as a manifestation of social pathology, as is seen in a cartoon from August 1968 in which a boy expresses his desire to grow up and become a man. As the man passes into old age the composition implies he has returned to the point from which he started, repeating his wish to "be anything I want to be." The joke is that the young boy aspires to manhood's responsibilities and the opportunity to "meet girls," whereas his older self craves an escape from responsibilities and 
women. The aging man seeks an easy dependency upon others, his shrunken posture embodying his shrivelled dreams and unfulfilled life (J. Feiffer Drawings 2001:076.808).

Despite these 1950s and 1960s precursors, Tantrum was fine-tuned to the 1970s. A prominent anxiety articulated during that decade was that society had fallen into the depths of narcissism and that Americans had become vain, complacent, and solipsistic. One recurring contention was that preoccupation with the self had displaced responsibility towards others. In the mid-1960s Feiffer wrote that America's "mass media has always been inbred, narcissistic, reactionary" (Great Comic Book Heroes 44) and in a 1971 interview with Playboy magazine he argued the United States had turned "narcissistically violent toward the outside world" (94). Feiffer was acutely aware of what I will call America's narcissism crisis, and the first two sections of this essay relate Tantrum's plot, dialogue, and imagery to the consciousness movement and interest-group politics that were prominent components of 1970s debates about narcissism. The flavor of these debates was apparent in a November 1978 interview in which Feiffer compared the nation's response to the 1960s to a human's response to massive shock. He contended America was in a state of denial, fear, and withdrawal, was unconcerned about future generations, and, despite the Civil Rights movement, Vietnam, and Watergate, it refused to give up a sense of innocence. This refusal drove the popularity of "nostalgia." Feiffer also gave some insight into the roots of Tantrum. Referring to his syndicated strip, Feiffer stated that he had received a highly favorable response to a six-week "miniseries" featuring a middle-aged male character that regressed back to infancy. Feiffer thought this character reflected "a condition" felt "acutely in society today, people....wanting to go back to the good old days....And mobs of people identified with it, it's got a very strong reaction" (Feiffer and Kane). Many reviewers saw Tantrum as a satirical observation on American narcissism, ${ }^{1}$ and Feiffer agreed that it had "a lot to say about our current public mood" (qtd. in Cowan C-3). 
The final section of this article elaborates how Feiffer's decision to create Tantrum as a long comics narrative was expressive of the text's social critique. We should pay attention to the artist's avowed motives because they are not easily reconciled with established histories of the graphic novel. Scholars often posit that the increasing visibility of the graphic novel in the last forty years has been underpinned by the assumption that a story told in comics does not have to be solely aimed at children. One of the few academics to examine Tantrum, Josh Lambert, argues that (along with Will Eisner's 1978 A Contract with God) Feiffer's book was "revolutionary" for rejecting, "more forcefully and lastingly than anyone had before, the misperception that comics are suitable only for children, and thereby helped to usher in the age of the graphic novel" (45). The teenage Feiffer had worked for veteran comics creator Will Eisner and was aware of the contention in the late 1970s that the graphic novel would elevate the medium from childish diversion to adult art form. But I want to disrupt the interpretation of Tantrum as a text that rejected "the misperception that comics are suitable only for children." Feiffer chose to narrate Leo Quog's story as a "novel-incartoons"2 precisely because Feiffer perceived comics to be an inherently juvenile form and therefore the most "appropriate" (J. Feiffer Papers Box 56 Folder 2) mode to engage with the national conversation about narcissism. The narcissist was often figured as an infantilized self, and the end of this article argues that Feiffer was not jettisoning the association of comics with childishness; he was foregrounding that very association, using the hybrid nature of Tantrum to underline how blurred the boundary between adult and infant had become in 1970s America.

In this decade journalists, politicians, and academics attacked their fellow citizens for abandoning the commitment to the public good and adopting a cult of the self. The psychoanalytical concept of narcissism was reworked to account for "a distinctively American malady associated with affluence and abundance" (Lunbeck 5). Tom Wolfe's 
article "The Me Decade and the Third Great Awakening" (1976) contributed another longlasting phrase to the lexicon but narcissism was the dominant term, its usage climaxing with Christopher Lasch's bestseller The Culture of Narcissism (1979). ${ }^{3}$ The most philosophically dense contributions to the debate constructed 1970s America at the leading edge of deep historical shifts in the capitalist world: for all their political differences, Daniel Bell's The Cultural Contradictions of Capitalism (1976) and Richard Sennett's The Fall of Public Man (1977) diagnosed similar ills, a "hedonistic age" that redefined moral conduct in terms of how authentically one articulated the self (Bell 72; Sennett 12). Directly influenced by Lasch's book (Zaretsky 214-21), on 15 July 1979 President Jimmy Carter used a televised address to lament the nation's "crisis of confidence." Carter claimed that Americans "now tend to worship self-indulgence and consumption" and that individual identity was fruitlessly predicated on the acquisition of material goods (A10).

Historians have been more balanced in their evaluation of the 1970s and it is now unfashionable to see the decade as a period of complacency, introversion, and stasis. ${ }^{4}$ Edward D. Berkowitz asserts it "was an era not of narcissism but of activism" (177) and, far from witnessing a retreat from political commitment, the major grassroots campaigns of the 1960s inspired an explosion of successors including environmentalism, the gay rights movement, the disability rights movement, feminism and anti-feminism, the American Indian Movement, protests against nuclear power, the rise of the New Religious Right, and many state-specific anti-tax campaigns. The historiographic impulse to revise the picture of an America gorged on wealth and sunk in solipsism is also present in the intellectual histories that relate the narcissism crisis to the concept's multiple valences in psychoanalytic thought (Lunbeck) or which show the complex and contested legacy of Lasch's book (Zaretsky 183-221).

Through formal analysis, archival research, reception history, and historical contextualization, this article elaborates how Leo's reversion to infancy offers a critique of 
the narcissism crisis. 1970s society was read as infantilizing because it encouraged a needy generation of narcissists who prioritized individual desire and demanded instant gratification. Lasch's Culture of Narcissism described a self-absorbed culture in which the subject "regresses into [an] infantile, empty self" (12-13) and Otto Kernberg, an oft-quoted psychoanalyst in the 1970s, thought that adults whose sense of self-worth came from their appearance and possessions had failed to outgrow the normal narcissism of childhood (Lunbeck 59-70). Narcissism and infantilization were also associated via popular alternative psychotherapies encouraging adults to regress back to youth; these new therapeutic practices were interpreted as a major contributing factor to the country's malaise.

Even though Leo Quog's exploits offer a commentary on collective narcissism and infantilism we should not jump to the conclusion that Tantrum is an outright excoriation of America's pathological condition. For one thing, the politics that Feiffer avowed in the late 1970s were not those of Lasch or his peers. In sounding the alarm about the erosion of patriarchal authority Lasch's Culture of Narcissism had many affinities with the criticisms of the 1960s made by America's New Religious Right, laying the blame for family disunity at the feet of the New Left, feminism, and the welfare state. A common allegation was that America's middle class was afflicted by a "growing ambivalence about biological reproduction" (Zaretsky 192). Lasch's framing of the debate underlines how far these fears were gendered. For critics of American narcissism, the choice not to have children-which, for feminists, was a potentially liberating one-was conceived as selfish, motivated by hedonism, and self-destructive (Zaretsky 199). Feiffer sympathized with the baby boomers' refusal to grow up if maturity was measured in terms that were hypocritical and jejune. Finally, in a more recent phase of his career Feiffer has enjoyed success as a writer and illustrator of children's books, and his writings from the 1960s indicate a keen sensibility about the vulnerabilities and precious pleasures of childhood. Feiffer was highly conscious of 
where comics stood in the hierarchy of American culture but Tantrum was not undertaken to redeem comics or to censure fellow citizens for childishly denying their responsibilities. Feiffer was, however, clearly thinking closely about the numerous lamentations about the state of the nation.

\section{Psychotherapy as Narcissism}

Like so many essays from the 1970s, Wolfe's "The Me Decade and the Third Great Awakening" attacked the 'consciousness movement ${ }^{5}$ as the paradigm of American narcissism. Lasch devoted the first chapter of Culture of Narcissism to the consciousness movement:

Having no hope of improving their lives in any of the ways that matter, people have convinced themselves that what matters is psychic self-improvement: getting in touch with their feelings, eating health food, taking lessons in ballet or belly-dancing, immersing themselves in the wisdom of the East, jogging, learning how to "relate," overcoming the "fear of pleasure." (Lasch 4-5)

The consciousness movement covered a bewildering variety of self-exploring practices, including the unorthodox psychotherapies criticized as master signifiers of the narcissism crisis. These were caricatured by Lasch as endorsing "the overthrow of inhibitions and the immediate gratification of every impulse" (12-13). In a 1978 commencement address Feiffer asserted that the nation's "fastest growth industry has become instant-answer clinics...in league with crackpot guru and therapy bashes which teach us how to love, feel, relate, think, stop thinking, become whole, become parts, simply become" (J. Feiffer Papers 56.2). In an interview published in December 1977 Feiffer thought the desire for "personal salvation" had led Americans into "fake therapies or religion" (26). 
Some of these therapies asked patients to relive birth or infancy: in Nude Therapy screaming naked therapands re-experienced birth in the faux-amniotic ambience of California's swimming pools (Nicholson). Arthur Janov's Primal Therapy was first practiced in Los Angeles in 1967 and his book The Primal Scream (1970) had sold 200,000 copies by 1972. Janov theorized that Primal Pain, encountered and then repressed in young life, was the root cause of all neurosis, and his model posited parents as neglectful, abusive, or smothering. Primal Therapy encouraged patients to cry, thrash, and scream in order to relive deep-rooted Pain and thus remove the neurosis created by that Pain's repression. Janov used childhood props to encourage the reliving of Primal Pain, including teddy bears, baby bottles, and cribs. Patients at Janov's Primal Institute could reportedly "relive the trauma of birth" by clambering through a birth simulator constructed from "tied-together inner tubes" (Keen 86; see also Keerdoja et al. 12). After he screams himself back to infancy Leo plans to surround himself with nurturing influences and he resents the emotionally barren parenting he experienced the first time round. His project—and the refusal of his parents to acknowledge him when he visits - chimes with the worldview of the new psychotherapies.

Leo's ferocious anger, a hallmark of Primal Therapy, had a formal corollary in Feiffer's style of drawing. Kirkus Reviews praised Tantrum's art for being Feiffer “at his loosest and most primal." In Feiffer's copy of this preview, these words have been underlined (J. Feiffer Papers 21.1). Earlier in the 1970s journalist Elizabeth Frank commented that Feiffer's style was becoming "wilder and angrier"; his "increasing mastery of articulate rage" had been achieved by working with a "looser, curlier line" and saving deep, solid blacks for backgrounds (80). This reaches its apotheosis in Tantrum: studying Feiffer's original art for the book, its areas of solid black were produced with the violent strokes of a magic marker. This is a technique redolent of infant energy and some of the pages in Tantrum were drawn on the reverse of Feiffer's headed writing paper, as if the artist's public, professional persona 
was improvising a means of keeping his younger alter ego occupied at short notice (J. Feiffer Drawings 2001:075.176).

In Tantrum Leo flies to Palm Springs in search of his sister-in-law Joyce. He finds her lounging in the blazing sunshine but emaciated and partially blinded by her "new diet" (Tantrum 121). Healthy eating was seen by Lasch as part of the promise of "psychic selfimprovement" (4-5). Joyce professes to be "dieting down to my essence" but using starvation to discover an authentic self is, she confesses, a "tricky" business, "like finding a needle in a haystack." Her guru Doctor Flux advises that the first step is "to shrink the size of the haystack until ultimately I reach essence. It's so fantastically logical you know it has to work" (Tantrum 128-29). Readers are surely meant to recoil at this colloquial analogy, a dangerous, delusive marriage of dietetics and homely common sense. While Doctor Flux's name connotes that she or he doctors the body in a state of change, it also means she or he is the physician of abnormal bodily discharge and the loss of vital fluids. Committed to whittling herself down to immaterial essence, Joyce contorts her body into horrendous shapes in order to "break my body off. Piece by piece" (138-41; see fig. 1). These impossible angles evoke yoga positions and Joyce seems to have grotesquely distorted yogic teachings, exaggerating asceticism in the service of reaching a higher consciousness.

California was associated with the consciousness movement more than any other state: Nude Therapy, Primal Therapy, est, and Gestalt Therapy were all based in California, as were the popular and powerful religions of Scientology and the People's Temple. As one historian writes, "fringe movements dedicated to exploring inner consciousness...could always be found, but they were generally concentrated in limited areas, above all southern California. During the 1960s and 1970s, such ideas went national" (Jenkins 36). The California-ness of Joyce's self-destruction is underlined when Leo, after a day of feeding Joyce back to health, screeches down the telephone to his mother that her son Charlie 
(Joyce's husband) is responsible for murdering his wife (Charlie has callously abandoned her to Doctor Flux's diet). In the Golden State, Leo berates his mother that her "favorite" Charlie, her "golden boy," is "a killer! A killer! A killer!” (131).

Leo hunts out Joyce and his brother's secretary Ms. Swallow because the two-yearold craves cuddles, caresses, and the warmth of a maternal breast. Leo's lust suggests he has reverted to an early stage of psychosexual development when "the people concerned with the child's feeding, care and protection... become its first sexual objects...primarily the mother or mother-surrogate" (Freud 16). One contemporary reviewer felt the "Freudian underpinnings" of Tantrum were so "blatant" it was scarcely worth commenting on the "[i]nfantile sexuality" in the text (Parloff 94). The sexual and intergenerational concerns of psychoanalysis were often worked into Feiffer's cartoons, novels, plays, and films, and the presence of these themes leads Josh Lambert to situate Tantrum in relation to 1970s Jewish American literature, which "became synonymous, for some observers, with the examination of characters' sexual desires, neuroses, and failures, and with the psychosexual dramas of parent-child relations" (Lambert 44-45, 56-58).

Specifically in relation to the concept of narcissism, which is not named in Feiffer's essay "Loathe Thy Neighbor" (1967) but was clearly on his mind, love is critiqued as a power struggle in which two people battle to be the most dependent member of the dyad: [True] LOVE is the dream of finding the mirror image of one's self writ large....LOVE, in the preferred reading of the word, means he or she who seeks you out, places a cool hand to your forehead, whispers, "There, there, it's going to be all right," and proceeds to arrange your life so that it is no longer necessary to be a grownup. There is no more profound disillusion than that of an outmanoeuvred mirror image who finds itself forced to place the first cool hand. (113) 
Feiffer is being deliberately disingenuous here, arguing for a revaluation of hate to balance out the hegemony of what goes under the sign of love. Still, Feiffer's work as a whole does suggest that he advocates a gentler version of this hypothesis. He often comments that middle-class chatter is a screen for latent fears and desires, and he seems sincere when he praises the "gradual opening toward HATE in our society." This anger is needed to smash the middle class's affectless "shell" of "alienation": "How good it will be to feel again!" ("Loathe" 175). Feiffer's juxtaposition of self-serving love against cathartic rage complicates the notion that Leo's tantrum is only narcissistic. His bouts of anger are narcissistic demands for others to cater to his needs, but they may also be necessary to transcend his alienated existence.

What would it mean to read Leo's regression in this way? In Palm Springs Leo is forced to take responsibility for Joyce and nurse her back to health. After he returns to physical adulthood, Leo spends the last few pages of Tantrum running around his apartment, tidying up and ordering his children to help him. Patriarchal authority is restored and Leo acts with gusto as the rule-enforcing father and attentive husband. If the plot ended here, a Laschian reading would see Tantrum as straightforward morality tale: a fulfilling life is possible if older males embrace their authority over younger family members. Leo thinks aloud that restaging his youth with better role models has failed (173). Readers could conclude that responsibilities which cannot be evaded are best executed willingly and energetically.

This was not the reading offered by Morris B. Parloff, chief of the Psychotherapy and Behavioral Intervention Section of the National Institute of Mental Health. Reviewing the graphic novel for Psychology Today, Parloff asserted that where Freud saw the inhibition of the pleasure principle as a means of attaining "security and success" Tantrum presents a world in which the opposite is true (95). Promising never to abandon Carol again, two-year- 
old Leo joins hands with his infant wife and they run into the sunrise (see fig. 2 and fig. 3). ${ }^{6}$ The couple agree to take responsibility for each other, but not their offspring, whose unreformed childishness is clear from their calls after their fleeing parents ("Mommy!" "Daddy!"). Leo says the only support they can expect in future will be financial ("We'll send 'em a check'), exposing his ill-disciplined children to the emotional vacuum of his own youth (182-83). The anonymous writer of the book's preview in Publishers Weekly (23 July 1979) thought that the moral was "irresponsibility will succeed if you work at it long enough" (154) and Parloff noted that Leo gains no profundity, denying everything, affirming nothing, and following a path of "evasion. It is truly a tale of our times" (97).

Before we read Tantrum as a celebration of apolitical irresponsibility let us remember that Feiffer sympathized with the youth movement whose interest in inner consciousness had supposedly evolved into the narcissism crisis. At the book's end Leo no longer sees his irresponsible solo journeying as a viable future. In 1979 Feiffer wrote out a series of notes for an address to the Friends of Memphis and Shelby County Public Libraries, and in these notes he linked the situation of Tantrum's protagonist to that of the nation: Leo "knows what he wants. Something else. So do we all. Welcome 2 1980” (J. Feiffer Papers 56.2). Feiffer hoped the 1980s would see a renewal of the radical energy of the 1960s (Feiffer and Kane) so perhaps the book's ending symbolizes some kind of political resistance. One could read Tantrum's last two pages as Leo coming to understand that he has a responsibility to his wife but he can get nothing he wants or needs as a worker in a bureaucratic capitalist system. After seeing the paranoid, hostile spaces that constitute America, the investment of Carol and Leo's love in each other seems a perfectly reasonable response to an unliveable society. Befitting Feiffer's hope of a resurgence of the 1960s in the 1980s, at Tantrum's end dropping out is a euphoric experience. The couple's excitement and hope underscore how unrewarding Leo's office job was, since he does not contemplate returning to it. 
But what if we read the conclusion of Tantrum against the grain of Feiffer's politics? Leo and Carol's flight certainly seems to symbolize reflection and reorientation at the end of the 1970s, yet I would argue we are glimpsing how selfhood, capital, and responsibility were being rewired by Reaganism, the dominant political ideology of the coming decade. The absconding Quogs have adapted to the 1970s narcissism crisis in highly cynical fashion, trusting to money to parent their children and having no intention of intervening if this fails. This monetarist solution was proffered the year before Ronald Reagan was voted into office. President Reagan followed Carter's lead in deregulating the US economy in the belief that free markets offer — as Reagan put it in 1981 — “creative, less expensive, and more efficient alternatives to solving our social problems" (qtd. in Schulman 246). National renewal was the rhetorical leitmotif of Reagan's presidency and a 1984 advertisement for his re-election announced it was "morning again in America," as it is on Tantrum's final page (Schulman 231). Feiffer's alignment of the book's conclusion with the 1980s makes sense, but unfortunately his optimism for progressive politics was not borne out by the decade peeping over the horizon.

\section{Identity Politics in the 'We Decade'}

Two closely aligned phenomena in the 1970s were the "rights revolution" and the growth of identity politics (Patterson 10). The rights revolution refers to how specific groups (such as women, gay people, African Americans, and disabled people) won valuable entitlements and support from the state. Counter-movements protested that legal protections for these groups infringed upon the rights of others, and when the Boston School Board addressed unofficial segregation by busing students to different parts of the city, the campaign to resist desegregation escalated into stabbings and riots (Berkowitz 171-76). Legal challenges to Affirmative Action programs were widely covered in the media, and the clamor 
for rights was interpreted not as an extension of America's democratic promises but as a battle between rival interest groups in "a slow-growth economy in which one person's victory meant another person's loss" (Berkowitz 158). For critics of the rights revolution, it represented further evidence of the nation's fragmentation (Patterson 70).

The rise of identity politics was inspired by the uplift of African American selfesteem that seemed to accompany the Civil Rights movement and Black Power. Chicana/o, Native American, and Asian American organizations all became more militant and visible in the 1970s and so-called white "ethnics" were keen to profess their own distinctive cultural practices and history, "ceasing to emulate WASP models" and affirming instead their "ethnic pride" and "their right to a separate identity" (Schulman 64-67, 80-84). A small but memorable example was the slogan 'Kiss Me I'm Italian,' emblazoned on the buttons worn on Italian Unity Day in June 1971 (Carroll 68).

Feiffer followed these developments closely and stated that America's "serious confrontation with racism" in the 1960s had actually led to "an increase in racism" (qtd. in Sheinman 28). In a 1978 commencement address delivered at the University of Oregon, Feiffer referred to the protests against desegregation in Boston and ventriloquized, "[the] middle class has rights, too, doesn't it?...What about reverse discrimination?" (J. Feiffer Papers 56.2). Feiffer lamented the country's fragmentation into "upper-, lower- and middleclass cults, each with its own competing objectives and at war with the rest" (Interview by M. Staats and S. Staats 22). In 1977 he objected to the white middle class complaining about other groups wanting a share of their privilege; Feiffer parodied this attitude when he told $L I$ magazine that "we in the middle and lower middle class are getting screwed, we want our rights too. White power" (26).

An earlier draft of page 107 of Tantrum (J. Feiffer Drawings 2001:075.247) suggests that Feiffer was thinking of infantilism as the defensive posture of white, middle-class 
Americans. Leo is delivering a series of life lessons to a two-year-old at an airport: be remote and suspicious, avoid reason, and — number seven on his list—“Don't mature! Mature people do the shit work!" In the published version Leo shouts that last line as the two-year-old trudges to his plane amongst a nondescript crowd of travellers (Tantrum 107). In the draft version the child walks past an African American security guard. The implicit meaning is that America's black population has made the mistake of growing up and accepting its responsibilities and thus has to perform "the shit work," such as airport security. Indulged white Americans may dodge this fate by adopting positions of permanent infancy, clinging to perceived slights that society perpetrates against them and using self-righteous victimhood as a screen to avoid seeing the injustice in front of them.

This is manifested in Tantrum in the form of the Others, a conspiracy of regressed adults secretly organizing to seize control of the country. Leo is asked to join them but he blows a raspberry and storms out (see fig. 4); the Others give chase and Leo spends the rest of the narrative trying to avoid them by posing as a genuine child. In his notes for a c.1980 speech, Feiffer commented that the competing factions in US society have the attitude, "Let's get our way before they get their way because if they get their way They'll do away with our way” (J. Feiffer Papers 56.3). At the Others' meeting, a demagogue articulates a similar sentiment about an unnamed rival group: "They want their way! Is it fair that they should have their way when we want our way?" The roaring crowd responds with a booming negative (Tantrum 81-82).

Leo does not refuse to become one of the Others because he morally objects to their plan to carve out a place of privilege for themselves in US society at the expense of other citizens. Leo is just as self-interested and suspicious as the Others and they both bear out comments Feiffer made in May 1978 that "[out] of the new cynicism surfaces a quarreling nation of self-righteous neighborhoods....Each America looking out of the corner of its eye, 
knowing for sure that the enemy lurks everywhere" (J. Feiffer Papers 56.2). When evading the Others at the airport, this sideways glance - visual shorthand for sneakiness - is used by Leo and his pursuers (Feiffer, Tantrum 92-95; see fig. 5). Leo is not morally superior to the Others: he rejects them because he resents their encroachment on his exceptionality. He takes their overtures towards him as a "personal reproach" because he thought he was "unique" (88).

In 1977 sociologist Richard Sennett argued that the narcissist sought ethnic and regional fraternity in order to place the self in an exclusive collective personality. Sennett calls this "fantasy of being a community" a "destructive gemeinschaft" because the self is only shared with a shrinking cohort of people. Alternative identity positions must be denied membership of the community to maintain its exclusivity (260-66). Tantrum is in sympathy with Sennett's argument, which explains why the Others have such murderous hatred towards Leo: his refusal to join them confounds their "fantasy of being a community." How can the Others build a movement based on shared identity when one of their own refuses the claims of fraternity, claims expressed in the exhortation, "Will you join us, brother baby?" (Feiffer, Tantrum 86). Leo turns the Others' symbolic protest, the raspberry blow, against them; the raspberry blow was meant to signify their strength and autonomy as a political "movement," underlined by the raised fist salute that accompanies it (85-87). Leo's "betrayal" is repugnant and one of the Others wails, "I can't stand it that one of our own gives us brrrp" (87). Leo's rejection of the Others constitutes a rejection of one permutation of 1970s narcissism, the exclusive "gemeinschaft," but his gesture is ultimately narcissism's perfect distillation: Leo's loyalty to his own self is the purest version of the Others' claim that his allegiance must be to the people who look and behave like him.

Through allusions to the consciousness movement and the rise of special interest groups, Tantrum drew the reader's attention to key aspects of the narcissism crisis. Leo's 
return to infancy was a correlate of contemporary debates in which narcissism in US society was read as degeneration of psychosexual development back to a phase normally left behind in childhood. There is also evidence to read Tantrum in relation to the psychotherapies that encouraged reliving infant experience; such therapies were frequently cited as the worst excesses of national narcissism. Crucially, Feiffer's perception of the United States in the 1970s informed his decision to use comics to tell the story of Leo Quog. Feiffer had achieved commercial and critical success as a screenwriter, dramatist, and novelist, so why did he now turn to a "novel-in-cartoons"?

\section{On Graphic Novels, Comics, and Childhood}

Comics scholars often propose that the uplift of comics' cultural status is related to the publication of long comics narratives in book form. The 1970s was a turning point in the development of the graphic novel (Baetens and Frey 54-73), and, despite being at a remove from the underground comix and independent comics publishers where vital experiments were fermenting, Feiffer was personally and professionally connected to key participants in the decade's novelization of comics. Will Eisner's A Contract with God (1978) used the term graphic novel on the front cover of the paperback edition and between 1946 and 1951 Feiffer worked on Eisner's The Spirit comic. Some of Feiffer's strips were reprinted in Will Eisner's Spirit Magazine (October 1978) and a copy of this issue (containing a feature and advert for Contract) was in Feiffer's possession (J. Feiffer Papers 6.7). Eisner's graphic novel came up when Feiffer and comics artist Gil Kane were interviewed together in November 1978. Kane had told Feiffer about Eisner's new “novel” and Feiffer was looking forward to reading it (Feiffer and Kane).

The seed for Feiffer's cartoon novel was planted by 13 January 1979, when the word “Tantrum” appears in his diary. Knopf paid Feiffer's advance in June 1979 (J. Feiffer Papers 
1.4 and 4.4) and in the same month Feiffer's interview in Quest/79 identified Tantrum as "a long cartoon novel" unlike "anything I've ever attempted." He saw it as a "great commitment of time" but was energized by the opportunity to work with "a form to be investigated, opened up, played with” (23). Reviewing Tantrum for the Toronto Star, Arn Saba identified Feiffer's book as a building block towards the establishment of comics' credibility. Saba hoped that Feiffer's "prestige might help legitimize the form"; after all, Feiffer's cultural activities in other media had given him the leverage to place his "comic-strip novel" with a “major publisher” (Saba H9). For Parloff, "Tantrum may look like a comic book and read like a comic book, but it is, in fact, a cartoon novel" (92), and many reviewers offered the same refrain: Tantrum was a novel in the guise of a comic book (Romine 9) and "sophisticated audiences" would enjoy this "latest venture" from the "master of the adult comic book" (Fern 12). Not every reviewer agreed it was a novel, with Kirkus Reviews protesting "it's more like a short-story in cartoons" and Saba's review calling it "a short story" rather than "truly being a novel" (Saba H9), but Feiffer referred to Tantrum as a "novel-in-cartoons" on the book's dustjacket, a "cartoon novel" (23) in his interview with Quest/79 (June 1979), and a "graphic novel" in notes for a speech (J. Feiffer Papers 56.2). However, Feiffer's designs were far more complicated than legitimating comics as an art form. Feiffer declared he was drawing Tantrum as a way of returning to "the kind of cartoons that made me fall in love with them as a kid" (qtd. in Herman 1) and it must be recollected that for Feiffer the comics of his youth were a low-grade medium reserved for children. Respectability was not on the agenda. In one of Feiffer's syndicated cartoons from 1965, a boy grows up before our eyes and his tastes mature from radio serials, comic books, and B-movies to swing music, slick magazines, and A-movies. His pleasures climax with stereo radio, literary quarterlies, and foreign films. But now, with the "pop-culture movement" ascendant in the mid-1960s, the adult listens to old radio serials, reads comic 
books, and watches the B-movies of his youth. In a cyclic move classic of Feiffer's comics for the Village Voice, this character is wearing his childhood clothes at the cartoon's end. Feiffer figures the nationally-mandated regression in taste as a loss of cultural principles and the character asserts in the final panel, "In a society without standards who needs to grow up" (J. Feiffer Drawings 2001:076.763).

What was this "pop-culture movement"? Feiffer was thinking of the popularity of Marvel Comics with college-age readers and the prominence of Pop Art works by Andy Warhol and Roy Lichtenstein (Wright 223-25). Feiffer himself contributed to the mid-1960s vogue for American popular culture with the book The Great Comic Book Heroes (1965). Feiffer edited this collection and contributed substantial essays on mid-twentieth-century comics. In an article of 9 January 1966, Feiffer noted that his reflections in The Great Comic Book Heroes would once have been "considered frivolous. But now, in an age of popeverything, they are pop-sociology.” The comic books of Feiffer's youth, along with "radio programs, old B movies, [and] old pulp magazines" were valuable for allowing social analysis of the 1930s, and they also shed light on the 1960s, when the division between what's criminal and what's not, what's culture and what's not, was apparently unclear. The pop-culture movement is of a piece with "a nostalgia that blots out the vapid, remorseless present with hoked-up excerpts out of the vapid, remorseless past." Feiffer was against the "deification" of "pop culture," reading it as a confused, paranoid country's "psychic need for mediocrity." Feiffer argued that America's middle class wanted to escape the messy vicissitudes of history by embracing the artifacts of the pop cultural past, which can only be socially endorsed by recasting those artifacts as art ("Pop" 7).

Feiffer resisted the idea of making comics respectable and in The Great Comic Book Heroes he asserted that comics are "junk." He was quick to clarify that this is not the same as saying that comics are worthless: 
Junk is a second-class citizen of the arts; a status of which we and it are constantly aware. There are certain inherent privileges in second-class citizenship. Irresponsibility is one. Not being taken seriously is another. Junk, like the drunk at the wedding, can get away with doing or saying anything because, by its very appearance, it is already in disgrace.... That's why it is needed so. (186)

Feiffer draws a further conclusion from this conception of comic books as sites of licentiousness. He paints a bleak picture of US childhood where young lives are regimented by the school system and controlled by authority figures; comics are a refuge from this, offering the young male reader "a place to hide where he cannot be got at by grownups." Plunging into a comic allowed Feiffer and his peers "to roam free, disguised in costume, committing the greatest of feats — and worst of sins....For a little while, at least, we were the bosses. Psychically renewed, we could then return above ground and put up with another couple of days of victimization" (Great Comic Book Heroes 188-89). Feiffer felt there was room "for junk in our culture...so long as it keeps its place. But good Lord, let's not make it respectable!" The social functions of comics outlined in The Great Comic Book Heroes were threatened by Pop Art's "deification" of comics ("Pop" 7) and in an unpublished draft of his 9 January 1966 article Feiffer wrote that making comics respectable "betrays the audience" they were intended for: "kids" (J. Feiffer Papers 23.5). These thoughts have important implications for the fusion of comics and novels in Tantrum.

In a series of notes in Feiffer's unpublished papers, seemingly for a public speech in 1979, the artist registered his self-consciousness regarding the lack of a tradition to which Tantrum belonged. There were "no real precedents in form. All my life learned thru reg. lessons. What not 2 do, pitfalls 2 avoid, excesses 2 steer clear of." With characteristic wit Feiffer mused that "working on this form $[\mathrm{I}]$ have 2 invent all the excesses. All seemed very 
risky," and he jokingly worried about being solely responsible for the project's mistakes and false starts. Would he be able to fail sufficiently to be a useful negative role model for his successors? Feiffer describes the book as "a combination of the cartoon form, the play form $\&$ the screenplay form. Therefore it is called a novel. A graphic novel" (J. Feiffer Papers 56.2). But why combine these forms together? What would the graphic novel provide that these other forms did not?

Put simply, Feiffer adopted this form because there was something apposite about satirizing an infantilized America via a cultural form conceptualized as a seedy, knockabout vehicle for youthful fantasies of power and escape. Feiffer planned to tell the Friends of Memphis and Shelby County Public Libraries that "Tantrum my cartoon novel [about] a man Leo seems 2 me symbolically right 4 the times I've been describing." He did not only mean that the plot was "symbolically right" but its combination of two cultural modes: "Form of book cartoon also a novel seemed appropriate 2 prevail[ing] schizophrenia. Looks like is 4 children but 4 grownups. Chose form which hasn't been worked in before: fit perfectly my own confusion" about "who \& what grownup is" (J. Feiffer Papers 56.2). Feiffer suggested that the blend of cartoon and novel, using a form for children while addressing an adult readership, was the "appropriate" mode for America's widespread cultural "schizophrenia."

Tantrum is a permutation of a recurring motif in Feiffer's body of work, namely childish, narcissistic adults. His first novel, Harry, the Rat with Women (1963), follows the romantic exploits of the vain, solipsistic Harry, whom the character Georgette Wallender perceives as "a spoiled, bewildered, self-indulgent, beautiful boy." When Harry moves back in with her, Georgette tries to "teach him how to put away his socks," determined to "train him to be a man" (81-82). There are even instances in Feiffer's oeuvre of adults insisting on being treated as children and child characters being cast loose in the grown-up world. But the form of Feiffer's 1979 "cartoon novel” differentiated Tantrum from Munro, the four-year-old 
drafted into the army in the comics collection Passionella and Other Stories (1959) and animated short Munro (1960), and from the eponymous protagonist in Feiffer's play Crawling Arnold (1961). Leo Quog occupies a genuinely indeterminate status, reasoning and conversing like an adult while occupying the physical body (and vulnerability) of an infant. This is not the case with these earlier characters because certain constraints relating to cultural form made it more difficult for the stage show and the animated cartoon to combine adult themes with a very young protagonist. In the animation, for instance, the nature of the intended viewer meant that sexually explicit material was never likely to be included. With its clueless authority figures, ear-catching sound effects, and semi-moralizing conclusion (after experiencing life in the military Munro is much more inclined to do what his mother asks him), children seem to be the target audience for the animated film. Unlike the ageblurring of Leo Quog, Munro is unambiguously marked as a child to the viewer, not least through his speech. There can be no confusion about his age status. While the animated film, like the comic, operates as a satire of military dogma, nothing in either of these versions is unsuitable for young eyes.

The form of Crawling Arnold (a one-act play) also limits how the protagonist can be imagined. Arnold is a man of thirty-five behaving like a child but, unlike the regressed Leo, he most definitely is a man of thirty-five and his regression is finally revealed to be a highly cynical performance. At home Arnold crawls on the floor, licks lollipops, and is engrossed in his coloring book, but he still drinks martinis and goes to work in a suit. By the play's end Arnold's infantile behavior appears to be a calculated ploy; Arnold confesses that as a child he enjoys less "rigid" morals and has rediscovered the value of being "naughty" (18). Leo's desire for female care may be symptomatic of infant sexuality but Arnold's motivation is fullblown adult lust, believing that crawling makes him more "attractive" (21) to the opposite sex. He tells this to Miss Sympathy, a psychiatric social worker who Arnold's parents hope 
will be able to cure their son. Arnold seduces Miss Sympathy and he starts undressing her at the play's conclusion, a repeat of what happened with the last social worker, who slept with Arnold "because she wanted to make [him] feel like a man." (21) Even Arnold's "naughty" (18) behavior, breaking the All Clear siren used to bring the Civil Defense drill to a close, serves his sexual goals because it ensures he is left alone with Miss Sympathy (his parents call hopefully from offstage, "Was that the all clear?") (22).

Arnold is not so much regressed, then, but playing at being regressed, and it is difficult to imagine how a transmogrification of the kind that Leo went through could be recreated on stage. Could a two-year-old actor learn the dialogue for a one-act play? Given the sexual themes involved, if a very young actor was used, would a theatre owner risk criminal proceedings for endangering the morals of a minor? The role of Arnold has to be performed by a fully grown man so even if Feiffer wanted the character to be an infant played by an adult actor what audiences would be seeing, suspension of disbelief or otherwise, would be a full-grown adult.

Cartooning provided the elasticity of visual expression Feiffer needed to realize the sight of an adult who physically regresses to infancy. A dramatic equivalent for this could be performed on stage but not the actual sight of a two-year-old with the speech of a middleaged man. And unlike the Munro comic, Feiffer's “cartoon novel” (with its full-frontal adult nudity on page 165) is not suitable for children, even if its adult-orientated plot has been screwed into a succession of images informed by the comics of Feiffer's youth and the scribbled cartoons of childhood. The form of Tantrum allowed Feiffer a rare opportunity to visualize a protagonist corporeally regressed back to infancy yet retaining the thoughts and speech of an adult.

Tantrum allowed Feiffer to put his spin on a kind of text that some of America's most eminent cartoonists had produced. While Feiffer claimed this form "hasn't been worked in 
before," long, book-format sequential art narratives had been appearing throughout the twentieth century, often published by East Coast trade presses and created by artists who otherwise earned a living providing illustrations for books, advertisements, newspapers, and magazines. These narratives frequently took the form of overt allegories used to make pointed social criticism, such as Lynd Ward's woodcut novel God's Man (1929), James Thurber's The Last Flower: A Parable in Pictures (1939), and Don Freeman's It Shouldn't Happen (1945). Around 1995 Feiffer recollected telling the Village Voice that he "wanted 2 get in print so I cd b famous so I cd b Thurber" (J. Feiffer Papers 58.1) and the form of Tantrum evokes the tradition just described: nearly every page of Tantrum contains a single panel, a point of comparison with the woodcut novels and Thurber's and Freeman's books. Having one panel to a page was read by one reviewer as "violat[ing] all the preconceptions one has about comic-book reading...it serves to circumvent prejudice against the book as a 'mere comic'”' (Saba H9). Further, its dustjacket, coffee-table bulk, and price $(\$ 8.95)$ all positioned Tantrum as a very different material proposition to the periodical comic book, usually costing well under $\$ 1$ per issue in the 1970 s.

In at least two ways, then-by inserting Tantrum into an esteemed tradition of illustration and avoiding the materiality of a periodical comic - the physical text was a way of accruing esteem, so it is difficult to propose that bidding for respect was completely out of Feiffer's mind when he conceived of Tantrum. In 1979 Feiffer described wrestling with the dilemma of being a cartoonist or a "serious writer." His ambitions led towards cartooning, but his "class pretensions" pulled him towards the profession of serious writer. The answer? “Write cartoon novel” (J. Feiffer Papers 56.2). David Macaulay’s 1979 review predicted that Tantrum would be marked as being “only cartoons!” and, as if to defuse such criticism, Feiffer is compared to Hieronymus Bosch, Norman Rockwell, and Max Ernst. Macaulay elaborates on that latter reference, positioning Tantrum on a line going back to the surrealist 
sequential art narrative in Max Ernst's 1934 series Une Semaine de Bonté (5). While at least one reviewer endorsed the idea that Feiffer got away with strong social criticism because people don't take cartoons seriously (Romine 9), the examples of Saba and Macaulay indicate that readers already enthusiastic about comics understood that what Tantrum was doing belonged to a discernible (and admired) publishing tradition.

Feiffer thought Tantrum was apt for the end of the 1970s because its fusion of media with different cultural statuses matched the "confusion" of his era. Feiffer bravely includes himself in this confusion and understood the pull of infantilization and its promise to magic away responsibility. Confronting adult readers with a format associated with childhood was potentially an audacious move, and the glee with which Feiffer went about creating Tantrum suggests he was attracted to its transgressive qualities, just as Leo's odyssey of regression affords a highly desirable imaginative flight from responsibility for the book's adult readers. Feiffer intuited that the national quest for irresponsible pleasure was a rich source of carnivalesque humor for old and young alike: "There are certain festive aspects 2 moral, intellectual \& cultural collapse. Tantrum takes pleasure in them + my hope is that if $u$ read this graphic novel...your pleasure will be no less than that of the $2 \mathrm{yr}$ old sitting on yr right" (J. Feiffer Papers 56.2). In the very act of enjoying Leo's rebellion against responsibility, the adult reader's pleasure is weighted equally with the infant's.

I agree with Josh Lambert that the "vexations of fatherhood" depicted in Tantrum are a means of "appealing to a mature audience (an audience of parents, not children)" who empathize with Leo's anxieties as a father and a son (56-58), but the book is not a disavowal of comics' association with childishness. It is, rather, an embrace of that association. Tantrum is a profane text because it refuses to be slotted into a clear cultural category with an agespecific audience, and while Leo Quog had many precedents in Feiffer's career, the graphic 
novel's space of profanity allowed the artist to produce his most dissonant permutation of the regressed adult motif yet.

Feiffer declared that the "excesses" of his graphic novel would be challenged, learnt from, and revised by succeeding comics creators, and that Leo (and the country) would find his period of infantilized self-indulgence to be as unsustainable as his depressing adulthood. To read Tantrum and its protagonist in this way is to posit them as negative models whose irresponsible pleasures are devised to give way to loftier, soberer endeavors. ${ }^{7}$ Feiffer foresaw better attempts at grappling with the novel-in-cartoons, and, symbolized in the dawn at Tantrum's end, more hopeful efforts to tackle America's socio-political paralysis. Longer, bolder, and more formally complex graphic novels would be published in the 1980s, but the arrival of the new decade did not presage a progressive breakthrough in US politics. Feiffer's novel-in-cartoons remains a compelling document of the tensions and paranoia of the 1970s, but to fully understand its social critique we must resist seeing Tantrum as simply another attempt by comics to achieve the status of rarefied culture for adults.

\section{UNIVERSITY OF EXETER}

\section{NOTES}

The author gratefully acknowledges the financial support of the AHRC. I would also like to thank Jules Feiffer and Katherine Collins for permission to quote from unpublished materials and Sara Duke for guiding me through the Feiffer items deposited at the Library of Congress. 
${ }^{1}$ See the preview of Tantrum in Publishers Weekly (23 July 1979) as well as Fern; Parloff; and Saba.

${ }^{2}$ As Tantrum was described on its dust-jacket.

${ }^{3}$ While this article references some of the 1970s literature on narcissism, the endnotes in Lunbeck provide the most extensive list of sources.

${ }^{4}$ See Berger; Berkowitz; Carroll; Foley; and Schulman.

${ }^{5}$ The consciousness movement was also labelled the awareness, self-awareness, human growth and human potential movement.

${ }^{6}$ Other readers have interpreted this as a sunset (Lambert 57; Rolens K12) but the darkness outside the bedroom window immediately before Carol's regression implies we are seeing the dawn.

${ }^{7}$ In this way Leo's odyssey and Tantrum are akin to the "normal" narcissism that Freud hypothesized was a universal phase of psychosexual development transcended with the formation of the ego-ideal (3).

\section{WORKS CITED}

Baetens, Jan, and Hugo Frey. The Graphic Novel: An Introduction. New York: Cambridge UP, 2015.

Bell, Daniel. The Cultural Contradictions of Capitalism. London: Heinemann, 1976.

Berger, Dan, ed. The Hidden 1970s: Histories of Radicalism. New Brunswick, NJ: Rutgers UP, 2010.

Berkowitz, Edward D. Something Happened: A Political and Cultural Overview of the Seventies. New York: Columbia UP, 2006. 
Capshew, James H. Psychologists on the March: Science, Practice, and Professional Identity in America, 1929-1969. Cambridge: Cambridge UP, 1999.

Carroll, Peter N. It Seemed Like Nothing Happened: America in the 1970s. New Brunswick, NJ: Rutgers UP, 1990.

Carter, Jimmy. "Transcript of President's Address to Country on Energy Problems." New York Times 16 July 1979: A10.

Cowan, Peter. “A Cartoonist Who’s a True Disbeliever.” Oakland Tribune 14 Dec. 1979:

$\mathrm{C} 1+$.

Feiffer, Jules. Crawling Arnold. Dramatists Play Service, 1963.

—. The Great Comic Book Heroes. New York: Dial Press, 1965.

—. Harry, the Rat with Women. London: Collins, 1963.

—. Interview by Larry DuBois. Playboy Sept. 1971: 81+.

—. Interview by Margaret Staats and Sarah Staats. Quest/79 June 1979: 22-23.

—. Interview by Peter Stone. LI 4 Dec. 1977: 25+.

—. "Loathe Thy Neighbor." Playboy Apr. 1967: 113+.

—. Passionella and Other Stories. 1959. London: Collins, 1960.

—. "Pop-Sociology." Sunday Herald Tribune 9 Jan. 1966, New York magazine supplement: 6-7.

—. Tantrum. New York: Knopf, 1979.

Feiffer, Jules, and Gil Kane. Interview by Arn Saba. 3 Nov. 1978, Billy Ireland Cartoon Library and Museum, Ohio State University, Columbus, CGA_ASKC_029_a and CGA_ASKC_029_b.

Fern, Alan. “Drawings.” New York Times Book Review 25 Nov. 1979: 12+.

Foley, Michael Stewart. Front Porch Politics: The Forgotten Heyday of American Activism in the 1970s and 1980s. New York: Hill and Wang, 2013. 
Frank, Elizabeth. “Jules Feiffer: Articulate Rage.” ARTnews Feb. 1974: 80.

Freud, Sigmund. Beyond the Pleasure Principle and Other Writings. Trans. John Reddick. London: Penguin, 2003.

Herman, Jan. "Feiffer Onstage: That's 'An Entertainment."' Sunday Sun-Times [Chicago] 24 June 1979, "Show" supplement: 1-2.

Jenkins, Philip. Decade of Nightmares: The End of the Sixties and the Making of Eighties America. New York: Oxford UP, 2006.

Jules Feiffer Drawings. Prints \& Photographs Division, Library of Congress. Washington, DC.

Jules Feiffer Papers, 1919-1995. Manuscript Division, Library of Congress. Washington, DC.

Keen, Sam. "Janov and Primal Therapy: 'The Screaming Cure.”' Psychology Today Feb. 1972: $43+$.

Keerdoja, Eileen, et al. “The 'Screaming Cure.” Newsweek 10 July 1978: 12.

Lambert, Josh. “'Wanna Watch the Grown-Ups Doin' Dirty Things?' Jewish Sexuality and the Early Graphic Novel." The Jewish Graphic Novel: Critical Approaches. Ed. Samantha Baskind and Ranen Omer-Sherman. New Brunswick, NJ: Rutgers UP, 2008. 43-63.

Lasch, Christopher. The Culture of Narcissism: American Life in an Age of Diminishing Expectations. 1979. New York: Norton, 1991.

Lunbeck, Elizabeth. The Americanization of Narcissism. Cambridge, MA: Harvard UP, 2014. Macaulay, David. Review of Tantrum, by Jules Feiffer. Washington Post Book World 13 Nov. 1979: 5.

Nicholson, Ian. "Baring the Soul: Paul Bindrim, Abraham Maslow and 'Nude Psychotherapy."' Journal of the History of the Behavioural Sciences 43.4 (2007): 337-59. 
Parloff, Morris B. “The Me Degeneration.” Psychology Today Dec. 1979: 92-97.

Patterson, James T. Restless Giant: The United States from Watergate to Bush v. Gore. New York: Oxford UP, 2005.

Review of Tantrum, by Jules Feiffer. Kirkus Reviews 1 Sept. 1979. www.kirkusreviews.com. Web. Accessed 11 Aug. 2016.

Rolens, Linda. "Feiffer Uses Pen of Anger, Malice.” Los Angeles Times 18 Nov. 1979: K12. Romine, Dannye. "Piggyback Fantasies: Child Is Father of Man - and Jules Feiffer Knows It." Charlotte Observer 18 Nov. 1979: 9.

Saba, Arn. “Jules Feiffer's 'Novel’ Maps Out Fresh Territory.” Toronto Star 15 Mar. 1980: H9.

Schulman, Bruce J. The Seventies: The Great Shift in American Culture, Society, and Politics. New York: The Free Press, 2001.

Sennett, Richard. The Fall of Public Man. 1977. London: Penguin, 2002.

Sheinman, Mort. “Jules Feiffer on Men, Women's Lib, Feiffer.” Women's Wear Daily 25 Jan. 1971: 1+.

“Tantrum.” Publishers Weekly 23 July 1979: 154.

Wolfe, Tom. "The Me Decade and the Third Great Awakening." The Purple Decades. London: Picador, 1993. 265-93.

Wright, Bradford W. Comic Book Nation. Rev. ed. Baltimore: Johns Hopkins UP, 2003. Zaretsky, Natasha. No Direction Home: The American Family and the Fear of National Decline, 1968-1980. Chapel Hill: U of North Carolina P, 2007. 